\section{Insertion and removal of Nexplanon}

The letter by Wallings ${ }^{1}$ draws attention to several important aspects of the insertion technique for Nexplanon as advised by the manufacturer and approved by the Clinical Effectiveness Unit of the Faculty of Sexula and Reproductive Health.

1. To place the arm under the head externally rotated and abducted to $90^{\circ}$ for any length of time is as unnatural as it is uncomfortable. This experienced and is likely to take time in insertion of the implant.

2. Difficult removal of a device in this position of the arm is also likely to be uncomfortable.

I believe it is more comfortable to place the arm on a pillow externally rotated at the shoulder and with the elbow at $90^{\circ}$ of flexion. The point of the medial epicondyle of the humerus is marked on the skin. The line diagram below shows the ulnar nerve in its passage from the is especially so if the operator is not

anterior to the posterior aspect on the medial side of the upper am. Nexplanon would be inserted $8 \mathrm{~cm}$ above the medial epicondyle in the area of the line shown in the diagram (figure 1).

As regards removal of a palpable but deeply placed implant I have not infrequently used the U-technique described by Parptoharjo and Wibowo ${ }^{2}$ for Norplant. This technique lends itself safely for removal of the single rod of Nexplanon. The use of a vasectomy forceps as described by $\mathrm{Li}$ et $a l^{3}$ for non-scalpel vasectomy is useful for this purpose. It secures the implant within the ring of the vas forceps. One may then use blunt dissection with gauze to expose the implant which is easily removed. Blunt dissection avoids damage to nerves and vessels. The advantage of the vas forceps is that because of its small diameter it cannot contain much more that the implant, if it is located and secured safely.

The Emory ${ }^{4}$ technique for implant removal may also be used but I find the original U-technique easier, safe and quicker.

\section{Kenneth Menon ${ }^{\circ}$}

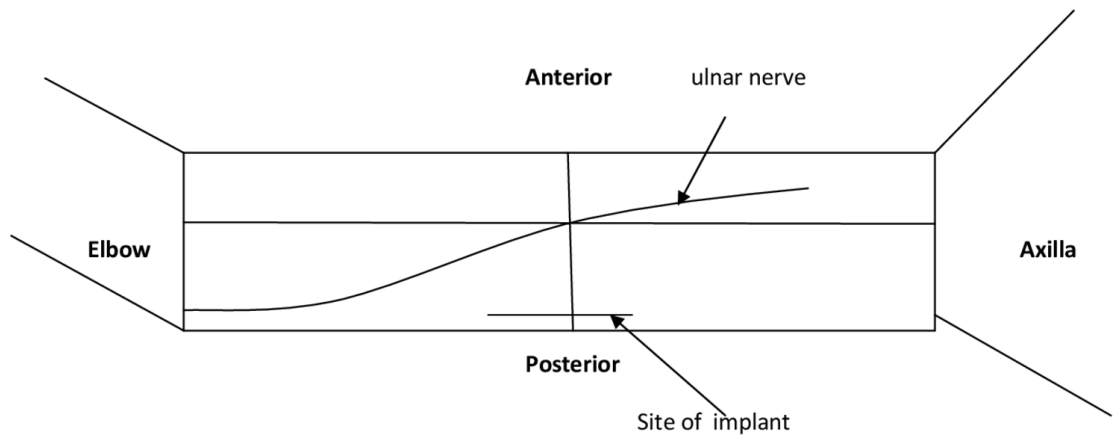

Figure 1 Surface anatomy for Nexplanon insertion.
The Ongar Health Centre, Ongar CM5 OAL, UK

Correspondence to Dr Kenneth Menon, The Ongar Health Centre, Ongar CM5 0AL, UK; kenmenon@aol.com

Funding The authors have not declared a specific grant for this research from any funding agency in the public, commercial or not-for-profit sectors.

Competing interests None declared.

Patient and public involvement Patients and/or the public were not involved in the design, or conduct, or reporting, or dissemination plans of this research.

Patient consent for publication Not required.

Provenance and peer review Not commissioned; externally peer reviewed. (C) Author(s) (or their employer(s)) 2021. No commercial re-use. See rights and permissions. Published by BMJ.

D Check for updates

Published Online First 15 May 2020

BMJ Sex Reprod Health 2021;47:70.

doi:10.1136/bmjsrh-2020-200635

\section{ORCID iD}

Kenneth Menon http://orcid.org/00000003-4421-4935

\section{REFERENCES}

1 Walling MR. New insertion site for Nexplanon insertion. BMJ Sex Reprod Health 2020;46:82.

2 Praptoharjo U, Wibowo S. The "U" technique: A new method for Norplant ${ }^{(\mathbb{*} *}$ implants removal. Contraception 1993;48:6:526-36.

3 Li SQ, Goldstein M, Zhu J, et al. The noscalpel vasectomy. J Urol 1991;145:3414.

4 Sarma SP, Hatcher R. The Emory method: a modified approach to Norplant ${ }^{\circledR}$ implants removal. Contraception 1994;49:551-6. 